\title{
Basic elements of eviscerated carcass and chemical composition of pectoral muscle in selected and unselected ducks (short communication)
}

\begin{abstract}
Forty 7-week-old ducks, 5 males and 5 females, from strains A44 and P66 and conservation flocks P33 and K2 were investigated. Their carcasses were dissected and chemical composition of the pectoralis major muscle was analysed. The carcasses of A44 and K2 drakes and ducks contained (\%) significantly more pectoral muscles compared to the carcasses of P66 and P33 drakes and ducks. The carcasses of K2 males contained significantly less (\%) thigh and lower thigh muscles than the carcasses of P66 and P33 males. The carcasses of K2 females had significantly less skin with subcutaneous fat compared to the carcasses of A44, P66 and P33 females. Pectoralis major muscle of drakes and ducks from conservation flocks contained more soluble collagen in total collagen than in animals from breeding strains. Moreover, the muscle of K2 males and females was found to contain more polyunsaturated fatty acids than in A44 males and P66 females, respectively. Pectoralis major muscle of drakes and ducks from both conservation flocks was characterized by a significantly lower energy value than in P66 drakes and ducks of both strains, respectively.
\end{abstract}

Key Words: ducks, tissue composition, meat quality, collagen, fatty acids

\section{Zusammenfassung}

Titel der Arbeit: Schlachtkörperbestandteile und chemische Zusammensetzung des Brustmuskels von selektierten und nicht selektierten Enten (Kurzmitteilung)

Das Versuchsmaterial umfasste 40 Enten in vier Gruppen im Alter von sieben Wochen. Jede Gruppe umfasste je 5 männliche und weibliche Tiere der Zuchtstämme A44 und P66 sowie Tiere der Erhaltungsherden P33 und K2. Untersucht wurden die Schlachtkörperbeschaffenheit und die chemische Zusammensetzung des großen Brustmuskels ( $m$. pectoralis major). Die Schlachtkörper sowohl männlicher als auch weiblicher Tiere des Zuchtstammes A44 sowie der K2 Herde wiesen signifikant höhere Gewichtsanteile des großen Brustmuskels auf als Tiere des Zuchtstammes P66 und der Erhaltungsherde P33. Im Vergleich zu männlichen Tieren der P66 und P33 Herde wurde im Schlachtkörper männlicher Tiere der K2 Herde ein niedrigerer Gewichtsanteil an Ober- und Unterschenkelmuskulatur ermittelt. Der Anteil an Haut und Hautfett im Schlachtkörper weiblicher Tiere der K2 Herde war signifikant niedriger als bei den weiblichen Tieren der Zuchtstämme A44 und P66 sowie der P33 Erhaltungsherde. Der große Brustmuskel männlicher und weiblicher Tiere in den Erhaltungsherden enthielt im Gegensatz zu den Tieren beider Zuchtstämme signifikant mehr lösliches Kollagen, bezogen auf den Gesamtkollagengehalt. Darüber hinaus ergab sich ein hochsignifikant größerer Gehalt an mehrfach ungesättigten Fettsäuren bei Tieren der K2 Herde beider Geschlechter gegenüber Tieren des A44 Zuchtstammes und der weiblichen Tiere des P66 Zuchtstammes. Der große Brustmuskel sowohl männlicher als auch weiblicher Tiere beider Erhaltungsherden zeigte einen niedrigeren Energiewert als bei den männlichen Tieren des Zuchtstammes P66 und den weiblichen Tieren beider Zuchtstämme.

Schlüsselwörter: Enten, Gewebezusammensetzung, Fleischqualität, Kollagengehalt, Fettsäuren

\section{Introduction}

Breeding work that has been carried out in Poland in five pedigree strains of Pekintype ducks (MAZANOWSKI et al., 1999; MAZANOWSKI and KSIĄŻKIEWICZ, 2004) is aimed to increase their muscling, primarily the content of pectoralis muscles in carcass, while decreasing the content of fat. Just like in other countries selected 
populations are kept alongside conservation flocks of ducks that provide genes useful for breeding (ALDERSON, 1990; SHAHIN et al., 2000; KSIĄŻKIEWICZ, 2002; ISGUZAR et al., 2002; KSIĄŻKIEWICZ, 2003; WAWRO et al., 2004). WITKIEWICZ et al. (2004) reported a greater number of muscle fibres of lower diameter in the pectoralis muscle of ducks from conservation flocks compared to breeding strains. From the viewpoint of meat quality, the greater number of finer fibres is more beneficial because fibre diameters are negatively correlated with meat tenderness (KŁOSOWSKA et al., 1994).

According to PINGEL (1990), selection of ducks for meat traits may deteriorate the eating quality of meat. Good quality of meat is determined, among others, by the content of soluble collagen and polyunsaturated fatty acids, and by the energy value of meat. Considerable differences between ducks of different origin in the content of total collagen and fatty acids in pectoral muscle were reported by SMITH et al. (1993), GÓRSKA and GÓRSKI (1997) and WOŁOSZYN et al. (2002, 2006).

The aim of this study was to compare ducks from breeding strains and conservation flocks for carcass tissue composition and the content of total collagen, soluble collagen and fatty acids in pectoralis muscle.

\section{Material and Methods}

The experiment was carried out with 7-week-old ducks from breeding strains A44 and P66 and conservation flocks P33 and K2 (Miniducks) from the Department of Waterfowl Breeding of the National Research Institute of Animal Production (ZHDW IZ) in Dworzyska. The above conservation flocks are included in the FAO World Watch List (2000) of farm animals. The breeding strains were created in Poland in the 1970s. Strain A44 was developed from Pekin ducks of English origin. Strain P66 was created using the old Polish strains of Pekin ducks: P11, P22, P33, P44 and P55. Flock P33 has undergone no selection since 1981. Flock K2 was created in 1978 at the ZHDW IZ in Dworzyska (KSIĄŻKIEWICZ, 2002). For this purpose were used wild mallard ducks (Anas platyrhynchos L.) and Pekin ducks. There is no selection in conservation flocks.

Birds were reared in groups of 100 (50 males and 50 females), first (until 3 weeks of age) in a closed facility with a controlled environment, and later in restricted, partially roofed outside runs on straw. Feed mixture contained 20\% crude protein and $12.13 \mathrm{MJ}$ AME energy until 3 weeks of age and 16.5\% protein and 12.34 MJ AME energy from the 4th week onwards. Feed was provided on an ad libitum basis. Housing, feeding and care conditions conformed to the current requirements for ducks presented by MAZANOWSKI and KSIĄŻKIEWICZ (2004) and were the same for all the groups. At 7 weeks of age, all birds were individually weighed and 10 animals (5 males and 5 females) were taken from each group for further analyses. Their body weights were close to the flock average for males and females in a group. The chosen ducks were slaughtered and their carcasses were cooled at $4{ }^{\circ} \mathrm{C}$ for $18 \mathrm{~h}$. Dissection analysis was performed according to the method of KISIEL and KSIĄŻKIEWICZ (2004).

Samples were taken from the rostral, middle and caudal part of the pectoralis major muscle. Total collagen was determined basing on colorimetric measurement of hydroxyprolin content (ETHERINGTON and SIMS, 1981). Soluble collagen was determined according to the procedure used for determination of total collagen following thermohydrolysis of the sample at $77^{\circ} \mathrm{C}$. Composition of fatty acids was 
analysed using gas chromatography (WAZSOWICZ, 1984). Energy (calorific) value was determined using a KL-10.

Statistical calculations for all the analysed traits were made using covariance analysis, and variance analysis was only performed for body weight. Analysis of significant differences was preceded by explorative data analysis to determine an adequate linear model. F-Snedecor and t-Student tests were used to examine the hypotheses about significant differences between the means. Because body weight can determine the magnitude of other analysed traits, it was included in the model as a concomitant (covariance) variable. The following linear model has been employed for body weight:

$$
\mathrm{y}_{\mathrm{ijkl}}=\mu+\mathrm{r}_{\mathrm{i}}+\mathrm{c}_{\mathrm{j}}+\mathrm{s}_{\mathrm{k}}+(\mathrm{rc})_{\mathrm{ij}}+(\mathrm{rs})_{\mathrm{ik}}+(\mathrm{cs})_{\mathrm{jk}}+(\mathrm{rcs})_{\mathrm{ijk}}+\mathrm{e}_{\mathrm{ijkl}}
$$

where: $\mathrm{y}_{\mathrm{ijkl}} \quad=$ body weight of ijkl-th bird

$\mu \quad=$ overall mean,

$\mathrm{r}_{\mathrm{i}} \quad=$ the fixed effect of strain

$\mathrm{c}_{\mathrm{j}} \quad=$ the fixed effect of year

$\mathrm{s}_{\mathrm{k}} \quad=$ the fixed effect of sex

$(\mathrm{rc})_{\mathrm{ij}}=$ the fixed effect of strain-year interaction

$(\mathrm{rs})_{\mathrm{ik}}=$ the fixed effect of strain-sex interaction

$(\mathrm{cs})_{\mathrm{jk}}=$ the fixed effect of year-sex interaction

$(\mathrm{rcs})_{\mathrm{ijk}}=$ the fixed effect of strain-year-sex interaction

$\mathrm{e}_{\mathrm{ijkl}}=$ the random residual effect connected with ijkl-th observation

Before the analysis, the Box-Cox transformation of data were performed. The computations were done by the use of SAS package programs (SAS, 1991).

Table 1

Mean values $(\overline{\mathrm{X}})$ and standard deviations (SD) for body weight and tissue composition of duck carcasses (Mittelwert und Standardabweichung für das Lebendgewicht und die Gewebezusammensetzung im Entenschlachtkörper)

\begin{tabular}{|c|c|c|c|c|c|c|c|c|c|}
\hline \multirow{3}{*}{ Trait } & \multirow{3}{*}{ Sex } & \multicolumn{4}{|c|}{ Breeding strains } & \multicolumn{4}{|c|}{ Conservative flocks } \\
\hline & & \multicolumn{2}{|c|}{ A44 } & \multicolumn{2}{|c|}{ P66 } & \multicolumn{2}{|c|}{ P33 } & \multicolumn{2}{|c|}{ K2 } \\
\hline & & $\overline{\mathrm{X}}$ & SD & $\overline{\mathrm{X}}$ & SD & $\overline{\mathrm{X}}$ & SD & $\overline{\mathrm{X}}$ & SD \\
\hline Body weight (g) & $\begin{array}{l}\text { males } \\
\text { females }\end{array}$ & $\begin{array}{l}3120^{a} \\
2870^{a}\end{array}$ & $\begin{array}{l} \pm 24.49 \\
\pm 24.49\end{array}$ & $\begin{array}{l}2830^{b} \\
2710^{b}\end{array}$ & $\begin{array}{l} \pm 24.49 \\
\pm 20.00\end{array}$ & $\begin{array}{l}3050^{\mathrm{a}} \\
2670^{\mathrm{b}}\end{array}$ & $\begin{array}{l} \pm 54.77 \\
\pm 24.49\end{array}$ & $\begin{array}{l}1810^{\mathrm{C}} \\
1730^{\mathrm{C}}\end{array}$ & $\begin{array}{l} \pm 48.99 \\
\pm 24.49\end{array}$ \\
\hline \multicolumn{10}{|c|}{ Content in carcass (\%): } \\
\hline hreast muscles & males & $14.2^{\mathrm{a}}$ & \pm 0.93 & $11.9^{\mathrm{bc}}$ & \pm 0.85 & $13.0^{\mathrm{b}}$ & \pm 1.35 & $13.4^{\mathrm{ab}}$ & \pm 1.74 \\
\hline Dreast muscies & females & $15.0^{\mathrm{a}}$ & \pm 1.18 & $12.4^{\mathrm{b}}$ & \pm 0.47 & $12.6^{\mathrm{b}}$ & \pm 0.94 & $14.2^{\mathrm{ac}}$ & \pm 1.84 \\
\hline thigh and lower & males & 12.8 & \pm 0.92 & $13.5^{\mathrm{a}}$ & \pm 0.44 & $13.3^{\mathrm{a}}$ & \pm 0.88 & $11.9^{\mathrm{b}}$ & \pm 1.25 \\
\hline thigh muscles & females & 13.0 & \pm 0.47 & 13.7 & \pm 0.68 & 13.3 & \pm 0.69 & 13.1 & \pm 0.64 \\
\hline skin with & males & 30.2 & \pm 1.64 & 29.4 & \pm 1.93 & 29.8 & \pm 1.65 & 31.0 & \pm 2.34 \\
\hline $\begin{array}{l}\text { subcutaneous fat } \\
\text { (with skin of neck) }\end{array}$ & females & $29.5^{\mathrm{a}}$ & \pm 1.09 & $30.1^{\mathrm{a}}$ & \pm 1.10 & $29.9^{\mathrm{a}}$ & \pm 2.14 & $24.4^{\mathrm{b}}$ & \pm 1.92 \\
\hline abdo & males & 2.2 & \pm 0.38 & 2.2 & \pm 0.30 & 2.3 & \pm 0.50 & 2.4 & \pm 0.66 \\
\hline abdomina & females & 2.2 & \pm 0.33 & 2.4 & \pm 0.50 & 2.6 & \pm 0.37 & 2.2 & \pm 0.53 \\
\hline
\end{tabular}

Mean values in rows with different letters are statistically different at $\mathrm{P} \leq 0.05$

\section{Results}

A44 drakes and ducks (Table 1) showed significantly greater body weight (by $225 \mathrm{~g}$ on average) than P66 birds. Males and females from breeding strains and the P33 flock had a significantly higher body weight compared to K2 birds. A44 drakes and ducks showed a significantly greater content of pectoralis muscles in carcass (by $2.2 \%$ on average) than P66 and P33 birds. In K2 birds of both sexes, significantly more pectoralis muscles (by approximately 1.7\%) were found than in P66 birds. Percentage 
of thigh and lower thigh muscles in carcasses of P66 and P33 drakes was significantly greater (by $1.5 \%$ on average) than in $\mathrm{K} 2$ drakes. K2 females were characterized by a significantly lower (by approximately 5.4\%) content of skin with subcutaneous fat (together with skin of neck) than females of breeding strains and flock P33.

Table 2

Mean values $(\overline{\mathrm{X}})$ and standard deviations (SD) for collagen content of pectoralis major muscle (Mittelwert und Standardabweichung für den Kollagengehalt im großen Brustmuskel)

\begin{tabular}{|c|c|c|c|c|c|c|c|c|c|}
\hline \multirow{3}{*}{ Collagen } & \multirow{3}{*}{ Sex } & \multicolumn{4}{|c|}{ Breeding strains } & \multicolumn{4}{|c|}{ Conservative flocks } \\
\hline & & \multicolumn{2}{|c|}{ A44 } & \multicolumn{2}{|c|}{ P66 } & \multicolumn{2}{|c|}{ P33 } & \multicolumn{2}{|c|}{$\mathrm{K} 2$} \\
\hline & & $\overline{\mathrm{X}}$ & SD & $\overline{\mathrm{X}}$ & SD & $\bar{X}$ & SD & $\bar{X}$ & SD \\
\hline \multirow{3}{*}{\multicolumn{10}{|c|}{$\begin{array}{l} \pm 0.06 \\
\pm 0.11\end{array}$}} \\
\hline & & & & & & & & & \\
\hline & & & & & & & & & \\
\hline in total & males & $5.49^{\mathrm{a}}$ & \pm 0.65 & $5.92^{\mathrm{b}}$ & \pm 0.45 & $4.04^{\mathrm{c}}$ & \pm 0.35 & $3.72^{\mathrm{c}}$ & \pm 0.57 \\
\hline protein & females & $7.18^{\mathrm{a}}$ & \pm 1.48 & $5.47^{\mathrm{b}}$ & \pm 0.84 & $4.34^{\mathrm{c}}$ & \pm 0.65 & $4.03^{\mathrm{c}}$ & \pm 0.26 \\
\hline in muscle & males & $0.080^{\mathrm{a}}$ & \pm 0.02 & $0.118^{\mathrm{b}}$ & \pm 0.02 & $0.115^{\mathrm{b}}$ & \pm 0.01 & 0.102 & \pm 0.01 \\
\hline weight & females & $0.053^{\mathrm{a}}$ & \pm 0.01 & $0.074^{\mathrm{a}}$ & \pm 0.02 & $0.143^{\mathrm{b}}$ & \pm 0.01 & $0.115^{\mathrm{c}}$ & \pm 0.01 \\
\hline \multicolumn{10}{|l|}{ Soluble (\%) } \\
\hline in total & males & $0.39^{a}$ & \pm 0.11 & $0.57^{\mathrm{b}}$ & \pm 0.09 & $0.57^{\mathrm{b}}$ & \pm 0.06 & 0.47 & \pm 0.05 \\
\hline protein & females & $0.25^{\mathrm{a}}$ & \pm 0.06 & $0.34^{\mathrm{a}}$ & \pm 0.10 & $0.68^{\mathrm{b}}$ & \pm 0.07 & $0.55^{b}$ & \pm 0.04 \\
\hline \multirow{2}{*}{$\begin{array}{l}\text { Soluble collagen in } \\
\text { total collagen (\%) }\end{array}$} & males & $8.60^{\mathrm{a}}$ & \pm 1.71 & $9.67^{\mathrm{a}}$ & \pm 1.68 & $14.20^{\mathrm{b}}$ & \pm 1.48 & $12.59^{\mathrm{b}}$ & \pm 1.55 \\
\hline & females & $3.56^{\mathrm{a}}$ & \pm 0.75 & $6.17^{\mathrm{b}}$ & \pm 1.23 & $15.89^{c}$ & \pm 1.05 & $13.53^{\mathrm{d}}$ & \pm 0.57 \\
\hline
\end{tabular}

Mean values in rows with different letters are statistically different at $\mathrm{P} \leq 0.05$

Birds of both sexes from conservation flocks contained about 1.99\% less total collagen in total protein compared to birds from breeding strains (Table 2). P66 and P33 males showed a statistically greater content of soluble collagen in pectoralis muscle (by $0.037 \%$ on average) and in total protein (by 0.18\%) than A44 males. Compared to females from breeding strains, females from conservation flocks had statistically more soluble collagen in pectoralis muscle (by approximately $0.065 \%$ ) and in total protein (by approximately $0.32 \%$ ). In birds of both sexes from conservation flocks, there was significantly more soluble collagen (by $7.05 \%$ on average) in total collagen than in birds from breeding strains.

Table 3

Mean values $(\overline{\mathrm{X}})$ and standard deviations (SD) for percentages of fatty acids in pectoralis major muscle and its energy value (Mittelwert und Standardabweichung des Prozentgehaltes an Fettsäuren und des Energiewertes im großen Brustmuskel)

\begin{tabular}{|c|c|c|c|c|c|c|c|c|c|}
\hline \multirow{3}{*}{ Trait } & \multirow{3}{*}{ Sex } & \multicolumn{4}{|c|}{ Breeding strains } & \multicolumn{4}{|c|}{ Conservative flocks } \\
\hline & & \multicolumn{2}{|c|}{ A44 } & \multicolumn{2}{|c|}{ P66 } & \multicolumn{2}{|c|}{ P33 } & \multicolumn{2}{|c|}{ K2 } \\
\hline & & $\bar{X}$ & SD & $\bar{x}$ & SD & $\bar{X}$ & SD & $\bar{x}$ & SD \\
\hline & males & 32.9 & \pm 0.80 & 34.3 & \pm 2.14 & 34.5 & \pm 1.25 & 34.5 & \pm 0.69 \\
\hline$\underline{0}$ & females & 34.0 & \pm 2.05 & 35.4 & \pm 2.12 & 34.5 & \pm 1.20 & 34.9 & \pm 0.80 \\
\hline$\underset{\tau}{\tilde{\sigma}} \odot$ monounsatu- & males & $55.7^{\mathrm{a}}$ & \pm 1.59 & $53.2^{\mathrm{ab}}$ & \pm 2.12 & $51.7^{\mathrm{b}}$ & \pm 1.32 & $50.4^{\mathrm{bc}}$ & \pm 0.75 \\
\hline$\nexists 2$ & females & 51.5 & \pm 2.00 & 52.3 & \pm 2.25 & 51.8 & \pm 1.34 & 49.9 & \pm 0.82 \\
\hline 党 polyunsatu- & males & $11.4^{\mathrm{a}}$ & \pm 0.90 & 12.5 & \pm 1.49 & 13.8 & \pm 1.01 & $15.0^{\mathrm{b}}$ & \pm 0.90 \\
\hline rated & females & 14.4 & \pm 2.01 & $12.3^{\mathrm{a}}$ & \pm 1.31 & 13.7 & \pm 1.05 & $15.1^{\mathrm{b}}$ & \pm 0.95 \\
\hline \multirow{2}{*}{$\begin{array}{c}\text { Energy value } \\
(\mathrm{kcal} / \mathrm{g})\end{array}$} & males & 1.58 & \pm 0.04 & $1.66^{\mathrm{a}}$ & \pm 0.13 & $1.52^{\mathrm{b}}$ & \pm 0.03 & $1.48^{\mathrm{b}}$ & \pm 0.02 \\
\hline & females & $1.61^{\mathrm{a}}$ & \pm 0.04 & $1.76^{\mathrm{b}}$ & \pm 0.04 & $1.48^{\mathrm{C}}$ & \pm 0.02 & $1.46^{\mathrm{C}}$ & \pm 0.03 \\
\hline
\end{tabular}

Mean values in rows with different letters are statistically different $\mathrm{P} \leq 0.05$

The muscle of K2 males and females contained significantly more polyunsaturated fatty acids (Table 3) than in A44 males (by 3.6\%) and P66 females (by 2.8\%), 
respectively. Pectoralis major muscle of drakes and ducks from both conservation flocks was characterized by a significantly lower energy value (by an average of 0.19 $\mathrm{kcal} / \mathrm{g}$ ) than in P66 drakes and ducks from both breeding strains, respectively.

\section{Discussion}

The content of total collagen and fatty acids in pectoralis muscle and the energy value of this muscle in Pekin ducks were the subject of a few investigations, e.g. SMITH et al. (1993), GÓRSKA and GÓRSKI (1997) and WOŁOSZYN et al. (2002). GÓRSKA and GÓRSKI (1997), when analysing Polish conservation flocks ducks P11, P22, P44 and P55, showed a similar proportion of total collagen in total protein to that found in our study in the breeding strains. The results obtained by these authors were greater by $1.91 \%$ on average than those obtained here in the conservation flocks. These differences are probably related to the origin of ducks and indicate greater value of the conservation flocks analysed. The content of monounsaturated fatty acids shown in the present study for ducks from conservation flocks was an average of $27.2 \%$ greater, and that of polyunsaturated fatty acids an average of $14.2 \%$ lower, than in ducks of these flocks analysed by WOŁOSZYN et al. (2002). In addition, in our studies we found an approximately $6.0 \%$ lower content of saturated fatty acids compared to the studies of WOŁOSZYN et al. (2002). These differences could be caused by the fact that WOŁOSZYN et al. (2002) examined the pectoralis (major and minor) muscle and by the feeding system (GRABOWSKI, 1993). Furthermore, the percentage of monounsaturated fatty acids found in the present work in ducks from breeding strains and conservation flocks was approximately $17.1 \%$ higher, and that of polyunsaturated approximately $3.1 \%$ lower, than in the pectoralis muscle of Pekin-type ducks as reported by SMITH et al. (1993). The content of saturated fatty acids in our study compared to the experiment of SMITH et al. (1993) was lower by about $11.0 \%$. Percentage of fatty acids in pectoralis muscle in the ducks of breeding strains and conservation flocks points to a high dietetic value of their meat. The muscle of ducks from conservation flocks compared to breeding strains was characterized by lower energy value, which nevertheless was about $0.26 \mathrm{kcal} / \mathrm{g}$ greater than in the studies of SMITH et al. (1993).

The satisfactory body weight found in 7-week-old ducks from the P33 conservation flock, and the considerable muscling and low fatness of carcasses, as well as greater percentage of soluble collagen and polyunsaturated fatty acids and lower energy value of the pectoralis major muscle in ducks from both conservation flocks, are indicative of good quality of this meat and the possibility of using these birds for producing safe food and in breeding programmes for further improvement of the existing, and for creation of new, strains of ducks.

ALDERSON, L.:

\section{References}

Genetic conservation of domestic livestock. C.A.B. International, U.K. (1990)

ETHERINGTON, D.J.; SIMS, T.J.:

Detection and estimation of collagen. J. Sci. Food Agric., 32 (1981), 539-546

GÓRSKA, A.; GÓRSKI, J.:

The changes of the total protein, collagen and fat content in Pekin duck crossbreds at the end of rearing period. Proc. $13^{\text {th }}$ Europ. Symp. on the Quality of Poultry Meat, Poznań (1997), 334-337

GRABOWSKI, T.:

The technology of poultry meat [in Polish]. WN-T, Warszawa (1993) 
ISGUZAR, E.; KOVAC, C.; PINGEL, H.:

Growth, carcass traits and meat quality of different local ducks and Turkish Pekins. Arch. Tierz., Dummerstorf 45 (2002), 413-418

KISIEL, T.; KSIĄŻKIEWICZ, J.M.:

Comparison of physical and qualitative traits of meat of two Polish conservative flocks of ducks. Arch. Tierz., Dummerstorf 47 (2004), 367-375

KŁOSOWSKA, D.; KŁOSOWSKI, B.; ROSIŃSKI, A.; ELMINOWSKA-WENDA, G.; SKRABKABŁOTNICKA, T.:

Microstructure of geese pectoralis muscle as related to some meat characteristics. Proc. $40^{\text {th }}$ Int. Congr. on Meat Science and Technology, Hague (1994), 1-7

KSIĄŻKIEWICZ, J.:

Reproductive and meat characteristics of Polish ducks threatened with extinction. Czech J. Anim. Sci., 47 (2002), 401-410

KSIĄŻKIEWICZ, J.:

Comparison of reproduction and carcass traits in light type of ducks of four conservative flocks over eight generations. Arch. Tierz., Dummerstorf 46 (2003), 377-389

MAZANOWSKI, A.; KSIĄŻKIEWICZ, J.; SZUKALSKI, G.:

Reproductive traits of ducks from maternal strains in two laying periods and meat traits of their offspring. Ann. Anim. Sci.-Rocz. Nauk. Zoot., 26 (1999), 191-203

MAZANOWSKI, A.; KSIĄŻKIEWICZ, J.:

Comprehensive evaluation of meat traits of ducks from two sire strains. J. Anim. Feed Sci., 13 (2004), 173-182

PINGEL, H.:

Genetics of growth and meat production in waterfowl. Poultry Breeding and Genetics - R.D. CRAWFORD, Ed (1990), pp. 691-703

SAS ${ }^{\circledR}$ USER'S GUIDE: Statistics, $7^{\text {th }}$ edition (1991), SAS Inst., Cary, NC

SHAHIN, K.A.; SHEMEIS, A.R.; ABDALLAH, O.Y.; SALEH, K.:

Effects of genetic control of subcutaneous fat deposition via using restricted selection indexes on live performance and carcass characteristics of Pekin ducklings. Arch. Tierz., Dummerstorf 43 (2000), 6977

SMITH, D.P.; FLETHER, D.L.; BUHR, R.J.; BEYER, R.S.:

Pekin duckling and broiler chicken pectoralis muscle structure and composition. Poult. Sci., 72 (1993), 202-208

WAWRO, K.; WILKIEWICZ-WAWRO, E.; KLECZEK, K.; BRZOZOWSKI, W.:

Slaughter value and meat quality of Muscovy ducks, Pekin ducks and their crossbreeds, and evaluation of the heterosis effect. Arch. Tierz., Dummerstorf 47 (2004), 287-299

WAॄSOWICZ, E.:

The fast method of fatty acids determination in colza seeds using gas chromatography [in Polish]. Przem. Spoż., 38 (1984), 353-355

WITKIEWICZ, K.; KONTECKA, H.; KSIĄŻKIEWICZ, J.; SZWACZKOWSKI, T.; PERZ, W.:

Carcass composition and breast muscle microstructure in selected vs non-selected ducks. Anim. Sci. Papers Reports, 22 (2004), 65-73

WOŁOSZYN, J.; KSIĄŻKIEWICZ, J.; ORKUSZ, A.; SKRABKA-BŁOTNICKA, T.; BIERNAT, J.; KISIEL, T.:

Preliminary evaluation of chemical composition of duck`s muscles from two polish conservative flocks. Proc. $48^{\text {th }}$ Int. Congr. Meat Science and Technology, Rome (2002), 374-375

WOŁOSZYN, J.; KSIĄŻKIEWICZ, J.; SKRABKA-BŁOTNICKA, T.; HARAF, G.; BIERNAT, J.; KISIEL, T.: Comparison of amino acid and fatty acid composition of duck breast muscles from five flocks. Arch. Tierz., Dummerstorf 49 (2006), 194-204

WORLD WATCH LIST FOR DOMESTIC ANIMAL DIVERSITY: FAO, UNDP, $3^{\text {rd }}$ edition (2000), 3-73, 351

Received: 2005-09-20

Accepted: 2006-05-10

Corresponding Author

Dr. KATARZYNA WITKIEWICZ

Department of Poultry Breeding, The August Cieszkowski Agricultural University of Poznań, Witosa 45, 61-693 POZNAŃ, POLAND

E-Mail: kasia20710@wp.pl 